\title{
PENGARUH PERTUMBUHAN EKONOMI DAN PAD TERHADAP KUALITAS PEMBANGUNAN SUMBER DAYA MANUSIA DAN TINGKAT KEMISKINAN
}

\author{
Teguh Khalid Billady ${ }^{1}$ \\ A. A. I. N. Marhaeni ${ }^{2}$ \\ ${ }^{1,2}$ Fakultas Ekonomi dan Bisnis Universitas Udayana (Unud), Bali, Indonesia \\ e-mail: teguhkhalidb@gmail.com
}

\begin{abstract}
The aim in this study is to determine the effect of economic growth and local regional revenue on the quality of human resource development and poverty levels, and to determine the effect of economic growth and local regional revenue on poverty levels through the quality of human resource development in districts / cities Bali province. Data collection methods used in this study are observation methods and use secondary data. The analysis technique used is path analysis. The results showed that economic growth and local regional revenue had a positive and significant effect on the quality of human resources and economic growth and local regional negative and significant affected the level of poverty and economic growth and local regional revenue had a negative and significant influence on the level poverty through the quality of human resource development in the districts / cities of the Province of Bali.
\end{abstract}

Keywords: economic growt; local regional revenue; quality of human resource development; the ministry of education.

\begin{abstract}
ABSTRAK
Tujuan dari penelitian ini adalah untuk mengetahui pengaruh pertumbuhan ekonomi dan pendapatan asli daerah terhadap kualitas pembangunan sumber daya manusia dan tingkat kemiskinan, serta untuk mengetahui pengaruh pertumbuhan ekonomi dan pendapatan asli daerah terhadap tingkat kemiskinan melalui kualitas pembangunan sumber daya manusia di kabupaten/kota Provinsi Bali. Metode pengumpulan data dalam penelitian ini adalah metode observasi non prilaku dan menggunakan data sekunder. Teknik analisis yang digunakan adalah analisis jalur. Hasil penelitian menunjukkan bahwa pertumbuhan ekonomi dan pendapatan asli daerah berpengaruh positif dan signifikan terhadap kualitas sumber daya manusia dan pertumbuhan ekonomi dan pendapatan asli daerah berpengaruh negatif dan signifikan terhadap tingkat kemiskinan serta pertumbuhan ekonomi dan pendapatan asli daerah secara tidak langsung mempunyai pengaruh negatif dan signifikan terhadap tingkat kemiskinan melalui kualitas pembangunan sumber daya manusia di kabupaten/kota Provinsi Bali.
\end{abstract}

Kata kunci: pertumbuhan ekonomi, pendapatan asli daerah, kualitas pembangunan sumber daya manusia, tingkat kemiskian 


\section{PENDAHULUAN}

Kemiskinan merupakan masalah yang kompleks bagi negara maju maupun negara berkembang, sehingga penanggulanganya memerlukan strategi yang tepat dan berkelanjutan (Vincent, 2009). Menurut Nilsen (2007) kemiskinan akan membatasi kemampuan individu untuk tetap sehat dan mengembangkan keterampilannya. Kemiskinan sampai saat ini masih menjadi masalah yang sulit untuk dicari solusinya. Penyebab kemiskinan dari sisi ekonomi yaitu, (1) karena kualitas penduduk yang rendah, (2) karena adanya perbedaan kualitas sumber daya manusia, dan (3) karena adanya perbedaan akses dalam modal (Kuncoro, 2004).

Kesejahteraan umum di Indonesia dapat digambarkan salah satunya berdasarkan tingkat kemiskinan penduduk di Indonesia. Berbagai kegiatan pembangunan nasional dilakukan pemerintah untuk meningkatkan kesejahteraan umum. Kemiskinan menjadi salah satu penyakit dalam perekonomian di hampir setiap negara, terlebih lagi di negara berkembang seperti Indonesia yang masih memiliki tingkat kemiskinan cukup tinggi dibandingkan dengan beberapa negara di sekitarnya.

Christian von Luebke (2009) berpendapat bahwa dalam transisi awal Indonesia menuju desentralisasi demokratis, tekanan masyarakat terkendala oleh masalah tindakan kolektif dan insentif politik yang sesat. Pemimpin pemerintah daerah, di sisi lain, memiliki kekuatan yang kuat dan insentif baru untuk reformasi kebijakan. Sebagai tanggapan terhadap debat tata pemerintahan yang baik, temuan penelitian ini menunjukkan bahwa kepemimpinan pemerintah merupakan penentu 
kebijakan yang penting, seringkali dibawah perkiraan, yang dapat mengkompensasi (atau memperparah) cek masyarakat yang lemah dalam transisi ekonomi.

Kemiskinan merupakan penyakit dalam ekonomi, sehingga harus disembuhkan atau paling tidak dikurangi (Addison, 2007). Upaya pengentasan Kemiskinan harus dilakukan secara komperhensif dan mencakup berbagai aspek kehidupan masyarakat (M. Muh Nasir et al., 2008). Negara peserta konferensi ini dituntut untuk dapat mengurangi jumlah penduduk miskin dan mengatasi kekurangan pangan hingga 50 persen pada tahun 2015 sehingga tujuan pembangunan nasional tercapai (Yogi dan Jember, 2012). Program-program pembangunan yang dilaksanakan selama ini telah memberikan perhatian besar terhadap upaya pengentasan kemiskinan (Budi Santosa dan Puji Rahayu, 2005). Salah satu tujuan pembangunan nasional yaitu meningkatkan kinerja perkonomian agar mampu menata kehidupan yang layak bagi seluruh rakyat sehingga dapat mengurangi tingkat kemiskinan di Indonesia (Prastyo, 2010).

Kemiskinan bukan hanya hidup dalam kekurangan uang dan tingkat pendapatan rendah, tetapi juga meliputi tingkat kesehatan, tingkat pendidikan serta ketidakberdayaan dalam menentukan jalan hidupnya sendiri (Chriswardani, 2005). Kemiskinan ditandai oleh rendahnya pendapatan per kapita dan lebarnya kesenjangan distribusi pendapatan. Penduduk miskin dalam hal ini pada umumnya bertempat tinggal di daerah-daerah pedesaan, dengan mata pencaharian pokok di bidang pertanian (Menurut Tadaro, 2000).

Hubungan atara Pendidikan, Pengangguran, dan Pertumbuhan Ekonomi Dengan Kemiskinan, mendapatkan hasil analisis jalur membuktikan bahwa antara 
pendidikan dengan kemiskinan memiliki hubungan langsung yang bersifat negatif, kecuali antara pengangguran dengan kemiskinan memiliki hubungan langsung yang bersifat positif (Seran Sirilius, 2017).

Analisis Faktor-Faktor yang Berpengaruh Terhadap Pengentasan Kemiskinan di Bali: Analisi Fem Data Panel, mendapatkan hasil menunjukkan bahwa persentase penduduk miskin yang menamatkan wajib belajar sembilan tahun tidak signifikan dalam menurunkan kemiskinan, jumlah penduduk, PDRB, dan share sektor pertanian berpengaruh positif signifikapn terhadap kemiskinan, sedangkan share sektor industri berpengaruh negatif signifikan (Sri Budhi, 2013).

Kemiskinan Di Provinsi Bali (Studi Komparatif Kabupaten/Kota Di Provinsi Bali), mendapatkan hasil analisi dengan Regresi Linier menunjukan secara simultan variabel AMH, AHH, TPAK, LPE, gini rasio dan daya beli masyarakat berpangur terhadap persentase jumlah penduduk miskin, tetapi secara parsial hanya variabel AMH, TPAK, gini rasio dan daya beli masyarakat berpengaruh (Wijantari dan Bendesa, 2016).

Provinsi Bali yang terkenal dengan destinasi pariwisatanya juga tidak luput dari permasalahan kemiskinan penduduk (Bali dalam Angka, 2017). Permasalahan kemiskinan di Provinsi Bali ini ditunjukkan dari masih tingginya angka kemiskinan di Provinsi Bali yang disajikan pada Tabel 1. 
Tabel 1.

Persentase Penduduk Miskin Per Kabupaten/Kota Di Provinsi Bali Tahun 2011-2016

\begin{tabular}{lc}
\hline \multicolumn{1}{c}{$\begin{array}{c}\text { Kabupaten/ } \\
\text { Kota }\end{array}$} & Persentase Penduduk Miskin per Kabupaten/Kota (Persen) \\
Jembrana & $\mathbf{2 0 1 6}$ \\
Tabanan & 5.33 \\
Badung & 5 \\
Gianyar & 2.06 \\
Klungkung & 4.44 \\
Bangli & 6.35 \\
Karangasem & 5.22 \\
Buleleng & 6.61 \\
Denpasar & 5.79 \\
Provinsi Bali & 2.15 \\
\hline Sumber: Badan Pusat Stik & 4.25 \\
\hline
\end{tabular}

Sumber: Badan Pusat Statistik Bali, 2017

Tabel 1 menunjukkan jumlah penduduk miskin di Provinsi Bali. Tingkat kemiskinan di kabupaten/kota Provinsi Bali memiliki rata-rata pengeluaran perbulan dibawah garis kemiskinan yang telah ditetapkan oleh Badan Pusat Statistika. Berdasarkan Tabel 1, tingkat kemiskinan di Provinsi Bali secara rata-rata tingkat kemiskinan Provinsi Bali pada tahun 2016 adalah sebesar 4,25 persen, artinya4,25 persen dari penduduk Provinsi Bali adalah Penduduk miskin. Ada 7 (tujuh) tingkat kemiskinan di atas tingkat kemiskinan rata-rata Provinsi Bali yaitu, Kabupaten Jembrana sebesar 5,33 persen, Kabupaten Tabanan sebesar 5 persen, Kabupaten Gianyar sebesar 4,44 persen, Kabupaten Klungkung sebesar 6,35 persen, Kabupaten Bangli sebesar 5,22 persen, Kabupaten Karangasem sebesar 6,61 persen, dan yang terakhir adalah Kabupaten Buleleng sebesar 5,79 persen. Sedangkan Kabupaten/kota yang lainnya dengan tingkat kemiskinan di bawah tingkat kemiskinan Provinsi Bali yaitu Denpasar sebesar 2,15 persen, dan Badung sebesar 2,06 persen. Tingkat kemiskinan tertinggi di Provinsi Bali adalah 
Kabupaten Karangasem sebesar 6,61 persen dan tingkat kemiskinan terendah adalah Kabupaten Badung 2,06 persen.

Pembangunan dalam lingkup daerah disamping meningkatkan produk domestik regional bruto dan laju pertumbuhan ekonomi daerah, juga perlu memperhatikan pembangunan manusia (Artana, 2015). Pembangunan manusia disebut-sebut sebagai tujuan akhir dari aktivitas manusia bukan tujuan dari pertumbuhan ekonomi (Poddar, dkk, 2014). Pembangunan manusia sendiri menjelaskan mengenai penghapusan kondisi-kondisi yang membatasi kemampuan dan menolak kesempatan untuk berpartisipasi dalam kegiatan ekonomi dan sosial yang normal (Mahesha dan Shivalingappa, 2011). Tingkat pembangunan manusia yang berdampak pada pertumbuhan ekonomi suatu bangsa tentu juga tergantung pada kondisi masyarakat lainnya (Gustav, 2004). Kualitas sumber daya manusia juga dapat menjadi faktor penyebab terjadinya penduduk miskin. Kualitas sumber daya manusia dapat dilihat dari indeks kualitas hidup/indeks pembangunan manusia (Hariwan, 2015).

Pemerintah daerah di Indonesia mengelola pajak secara tidak efisien. Biaya rata - rata administrasi perpajakan setempat sebagai persentase dari pendapatan yang dihasilkan diperkirakan lebih dari 50 persen. Namun ada variasi inefisiensi administratif yang luas pemerintah daerah. kondisi ini menimbulkan dilema bagi pemerintah pusat dalam memantau dan mengevaluasi kinerja administrasi perpajakan pemerintah daerah (Blane D. Lewis, 2006).

Peningkatan atau penurunan pertumbuhan ekonomi pada suatu daerah akan dipengaruhi oleh kualitas sumber daya manuasia yang dimiliki wilayah tersebut. 
Salah satu hal yang akan mempengaruhinya adalah Indeks Pembangunan Manusia. Sebagai tolak ukuran kualitas hidup, indeks pembangunan manusia dibangun melalui pendekatan tiga dimensi dasar, yaitu mencakup umur panjang dan sehat, pengetahuan serta kehidupan yang layak. Dalam pengukuran dimensi kesehatan, digunakan angka harapan hidup. Kriteria yang digunakan untuk mengetahui tingkat indeks pembangunan manusia yang disajikan pada Tabel 2.

Tabel 2.

Kriteria Tingkat Pembangunan Manusia Berdasarkan IPM

\begin{tabular}{cc}
\hline IPM & Kriteia \\
\hline$<50$ & Rendah \\
$50-65,9$ & Menengah Bawah \\
$66-79,9$ & Menengah Atas \\
$80-100$ & Tinggi \\
\hline
\end{tabular}

Sumber: BPS Provinsi Bali, 2016

Perkembangan indeks pembangunan manusia mencerminkan tingkat kesejahteraan yang rasakan oleh masyarakat. Meskipun demikian namun tinggi atau rendahnya tingkat indeks pembangunan manusia belum tentu mampu menggambarkan tingkat kesejahteraan yang dirasakan oleh masyarakat.

Tabel 3.

Indeks Pembangunan Manusia Provinsi Bali Menurut Kabupaten / Kota Periode 2009-2016 (persen)

\begin{tabular}{ccc}
\hline No. & Kabupaten/Kota & $\mathbf{2 0 1 6}$ \\
\hline 1 & Jembrana & 70,38 \\
2 & Tabanan & 74,19 \\
3 & Badung & 79,80 \\
4 & Gianyar & 75,70 \\
5 & Klungkung & 69,31 \\
6 & Bangli & 67,03 \\
7 & Karangasem & 65,23 \\
8 & Buleleng & 70,65 \\
9 & Denpasar & 82,58 \\
\hline
\end{tabular}

Sumber: Badan Pusat Statistik Provinsi Bali, 2016

Pada Tabel 3 dapat diketahui angka dari masing-masing komponen indeks pembangunan manusia, dimana indeks pembangunan manusia dari seluruh 
kabupaten/kota Provinsi Bali pada tahun 2016 tergolong dalam tahap menengah atas antara 66-79,9. Tingkat indeks pembangunan manusia akan dipengaruhi oleh tingkat pendapatan asli daerah sebagai sumber pembiayaan daerah.

Pengaruh Gini Ratio, Pengeluaran Non Makanan Per Kapita, Belanja Daerah Dan Laju Pertumbuhan Ekonomi Pada Indeks Pembangunan Manusia Kabupaten/Kota Di Provinsi Bali Periode 2004-2012, mendapatkan hasil penelitian menunjukkan bahwa baik secara parsial maupun simultan, variabel gini ratio, pengeluaran nonmakanan perkapita, belanja daerah, dan laju pertumbuhan ekonomi berpengaruh secara langsung pada indek pembangunan manusia pada 9 (sembilan) kabupaten/kota di Provinsi Bali. Hubungan positif antara keempat variabel bebas dan variabel terikat ini menunjukkan bahwa pemerintah hendaknya melakukan pemerataan pembangunan, belanja daerah, pendapatan perkapita, dan meningkatkan pertumbuhan ekonomi untuk menjaga agar indeks pembangunan manusia di Provinsi Bali mengalami peningkatan (Rustariyuni, 2014).

Pertumbuhan ekonomi Indonesia naik sedikit pada pertengahan 2016 namun masih berada di bawah angka yang diharapkan oleh pemerintah dan masyarakat. Terlepas dari berbagai reformasi yang dilakukan untuk meningkatkan efisiensi dan produktivitas, beberapa kebijakan memang buruk dan permasalahan implementasi masih tetap ada (Natasha Hamilton-Hart dan Günther G. Schulze, 2016).

Pertumbuhan ekonomi merupakan proses kenaikan output perkapita dalam jangka panjang. Pengertian ini mengandung tiga hal pokok yaitu proses, yaitu output perkapita jangka panjang (Cahyani, 2016). Pertumbuhan ekonomi 
merupakan masalah perekonomian suatu negara dalam jangka panjang, karena merupakan ukuran utama keberhasilan pembangunan dan hasilnya akan dapat dinikmati masyarakat sampai di lapisan paling bawah (Barimbing, 2015). Dalam suatu perekonomian kita tidak hanya sekedar membahas mengenai pentingnya PDB dan lapangan pekerjaan, namun juga perlu memperhatikan peran yang dapat mendorong pertumbuhan ekonomi (Suryahadi, dkk, 2012). Pertumbuhan ekonomi juga digunakan untuk menggambarkan pendapatan masyarakat secara keseluruhan. Indikator yang dapat digunakan untuk melihat keberhasilan pembangunan suatu daerah salah satunya adalah dengan meningkatkan pertumbuhan ekonomi (Pauzi, 2016). Pembangunan ekonomi pada dasarnya merupakan rujukan bagi pembangunan daerah atau dapat dikatakan dalam perencanaan pembangunan daerah, yaitu konsep pembangunan ekonomi yang disusun atau direncanakan oleh pemerintah pusat dijabarkan dalam rencana pembangunan daerah (Suwandika, 2015).

Analisis Pengaruh Jumlah Penduduk Yang Bekerja Dan Investasi Terhadap Ketimpangan Distribusi Pendapatan Melalui Pertumbuhan Ekonomi Kabupaten/Kota Di Provinsi Bali, mendapatkan hasil analisis ditemukan bahwa jumlah penduduk yang bekerja dan investasi berpengaruh positif dan signifikan terhadap pertumbuhan ekonomi. Pertumbuhan ekonomi berpengaruh positif dan signifikan terhadap ketimpangan distribusi pendapatan. Sementara itu, jumlah penduduk yang bekerja dan investasi tidak berpengaruh signifikan terhadap ketimpangan distribusi pendapatan. Pertumbuhan ekonomi merupakan variabel mediasi dalam pengaruh tidak langsung jumlah penduduk yang bekerja dan 
investasi terhadap ketimpangan distribusi pendapatan (Adipuryanti dan Sudibia, 2015).

Dampak Otonomi Fiskal, Pertumbuhan Ekonomi, dan Keterbukaan Daerah terhadap Ketimpangan Wilayah di Sumatera, mendapatkan hasil penelitian bahwa Pengaruh Otonomi Fiskal terhadap ketimpangan wilayah di Sumatera berpengaruh negatif dan signifikan. Pertumbuhan ekonomi merupakan proses kenaikan output perkapita dalam jangka panjang (Fajri, Delis dan Amzar, 2016). Pengertian ini mengandung tiga hal pokok yaitu proses, yaitu output perkapita jangka panjang. Proses menunjukkan bahwa perkembangan ekonomi dari tahun ke tahun akan terus mengalami perubahan, output perkapita mengaitkan aspek output total dan aspek jumlah penduduk, dan jangka panjang digambarkan sebagai kecenderungan perubahan perekonomian dalam jangka waktu tertentu yang di dorong oleh perubahan intern perekonomian (Arsyad 2010: 11).

Pendapatn asli daerah adalah pendapatan yang berasal dari daerah yang bersangkutan guna membiayai kegiatan - kegiatan daerah tersebut. Dalam kenyataannya pendapatan asli daerah terdiri dari empat jenis pendapatan, yaitu pajak daerah, retribusi daerah, hasil perusahaan milik daerah dan hasil pengelolaan kekayaan daerah yang dipisahkan dan lain-lain pendapatn asli daerah yang sah (Solihin, 2008).

Pendapatan asli daerah merupakan penerimaan daerah yang berasal dari sumber ekonomi asli daerah yang terdiri dari pajak daerah, retribusi daerah, dan lain-lain (Abdul Halim, 2007). pemerintah daerah bertanggung jawab untuk menyediakan barang publik yang mendasar seperti pendidikan, kesehatan, 
perawatan medis, dan lain-lain. Baik buruknya pengelolaan keuangan daerah akan berpengaruh pada Pendapatan Asli Daerah suatu daerah (Ping dan Bai, 2005).

Pendapatan perkapita merupakan indikator untuk melihat daya beli suatu daerah (Kuncoro, 2004). Pendapatan perkapita dapat diartikan sebagai jumlah dari nilai suatu barang dan jasa rata-rata yang tersedia bagi penduduk suatu Negara pada suatu periode tertentu (Bibi, 2006). Besarnya pendapatan perkapita sering digunakan sebagai pembanding tingkat kemakmuran di berbagai daerah (Norton, 2002). Pendapatan perkapita dapat diperoleh dari tahun tertentu dibagi dengan jumlah penduduk suatu negara pada tahun tersebut (Sadono Sukirno, 2004:423).

Salah satu sumber pembiayaan pembangunan Pemerintah provinsi Bali adalah Pendapatan Asli Daerah. Menurut (Mardiasmo, 2002:132) pendapatan asli daerah adalah penerimaan yang diperoleh sebagai sektor pajak daerah, retribusi daerah, hasil perusahaan milik daerah, hasil pengelolaan kekayaan daerah yang dipisahkan dan lain-lain pendapatan asli daerah yang sah. Menurut (Anom Iswara dan Indrajaya, 2014) ditemukan hasil bahwa tingkat pendidikan memiliki pengaruh negatif dan signifikan terhadap tingkat kemiskinan. Hasil selanjutnya menunjukkan bahwa pendapatan asli daerah dan pendapatan perkapita secara parsial tidak berpengaruh terhadap tingkat kemiskinan. Serta, pendapatan asli daerah, pendapatan perkapita, dan tingkat pendidikan secara simultan berpengaruh signifikan terhadap tingkat kemiskinan.

Beberapa perbedaan dalam istilah perkembangan ekonomi dan pertumbuhan ekonomi. Perkembangan ekonomi merupakan perubahan spontan dan terputusputus dalam keadaan stasioner yang senantiasa mengubah dan mengganti situasi 
keseimbangan yang ada sebelumnya, sedangkan pertumbuhan ekonomi adalah perubahan jangka panjang secara perlahan dan mantap yang terjadi melalui kenaikan tabungan dan penduduk (Schumpeter dan Hicks dalam Jhingan, 2004:4).

Pertumbuhan ekonomi adalah peningkatan kemampuan suatu negara (daerah) untuk menyediakan barang-barang ekonomi bagi penduduknya, yang terwujud dengan adanya kenaikan output nasional secara terus-menerus yang disertai dengan kemajuan teknologi serta adanya penyesuaian kelembagaan, sikap dan ideologi yang dibutuhkannya (Simon Kuznets dalam M.L Jhingan, 2004:57).

Pertumbuhan ekonomi sebagai suatu ukuran kuantitatif yang menggambarkan perkembangan suatu perekonomian dalam suatu tahun tertentu apabila dibandingkan dengan tahun sebelumnya (Sukirno, 2006:9). Landasan teori tentang pertumbuhan ekonomi yang ada dalam penelitian ini menggunakan konsep teori menurut (Boediono, 1999) dimana kemiskinan merupakan proses kenaikan kapasitas produksi dalam suatu perekonomian secara berkesinambungan menuju kearah yang lebih baik yang diwujudkan dalam bentuk kenaikan pendapatan nasional (PDB) maupun daerah (PDRB) dalam jangka panjang, sedangkan Produk Domestik Regional Bruto sendiri menurut BPS merupakan jumlah nilai tambah yang dihasilkan oleh seluruh unit produksi, baik berupa barang dan jasa dalam suatu wilayah. Pengukuran pertumbuhan ekonomi dalam penelitian ini menggunakan Produk Domestik Regional Bruto Atas Dasar Harga Konstan (PDRB ADHK) dengan tahun dasar 2000 .

Menurut UU No. 28 tahun 2009 pajak daerah, yang selanjutnya disebut pajak, adalah kontribusi wajib kepada daerah yang terutang oleh orang pribadi atau badan 
yang bersifat memaksa berdasarkan Undang-Undang, dengan tidak mendapatkan imbalan secara langsung dan digunakan untuk keperluan daerah bagi sebesarbesarnya kemakmuran rakyat. Seperti halnya dengan pajak daerah pada umumnya, pajak daerah mempunyai peranan ganda yaitu (1). Sebagai sumber pendapatan daerah (budegtary), (2). Sebagai alat pengatur (regulatory) (Abdul Halim, 2004:94)

Kemiskinan menurut Badan Pusat Statistika (2000) merupakan keadaan dimana seseorang individu atau sekelompok orang tidak mampu memenuhi kebutuhan dasarnya, seperti makanan, pakaian, tempat berlindung, pendidikan, dan kesehatan yang dianggap sebagai kebutuhan minimal dan memiliki standart tertentu. Kemiskinan bersifat kompleks artinya kemiskinan tidak muncul secara mendadak, namun memiliki latar belakang yang cukup panjang dan rumit sehingga sangat sulit untuk mengetahui akar dari masalah kemiskinan itu sendiri, sedangkan kemiskinan bersifat multidimensional artinya melihat dari banyaknya kebutuhan manusia yang bermacam-macam, maka kemiskinan pun memiliki aspek primer berupa kemiskinan akan aset, organisasi sosial politik, pengetahuan, dan keterampilan, serta aset sekunder berupa kemiskinan akan jaringan sosial, sumbersumber keuangan, dan informasi.

UNDP (United Nations Development Programme) mengatakan bahwa, pembangunan manusia adalah suatu proses untuk memperbesar pilihan-pilihan bagi manusia (a process of enlarging people's choices). Konsep atau definisi pembangunan manusia tersebut pada dasarnya mencakup dimensi pembangunan yang sangat luas. Dalam konsep pembangunan manusia, pembangunan seharusnya dianalisis serta dipahami dari sudut manusianya, bukan hanya dari pertumbuhan 
ekonominya. Sebagaimana dikutip dari UNDP (Human Development Report, 1995:103).

Analisis Pengaruh Pad, Dau, Dak, Dan Belanja Pembangunan Terhadap Pertumbuhan Ekonomi, Kemiskinan, Dan Pengangguran: Pendekatan Analisis Jalur. Penelitian ini menggunakan pendekatan kuantitatif. Dalam penelitian ini peneliti menggunakan statistik deskriptif dan regresi linier berganda untuk melakukan analisis jalur terhadap variabel-variabel penelitian. Hasil dari penelitian tersebut menunjukan pengujian secara langsung dengan regresi berganda menunjukkan PAD berpengaruh positif terhadap pertumbuhan ekonomi, sedangkan DAU berpengaruh negatif terhadap pertumbuhan ekonomi. Untuk pengujian secara langsung untuk pengaruh pertumbuhan ekonomi terhadap kemiskinan dan pengangguran menunjukkan adanya pengaruh yang signifikan, tetapi pertumbuhan ekonomi berpengaruh negatif terhadap kemiskinan dan berpengaruh positif terhadap pengangguran (Setiyawati dan Hamzah, 2007).

Analisis pengaruh tingkat kemiskinan, pengeluaran pemerintah sekor pendidikan dan kesehatan terhadap indeks pembangunan manusia di Provinsi Jawa Tengah tahun 2007-2009 mendapatkan hasil bahwa variabel jumlah penduduk miskin, pengeluaran pemerintah sekor pendidikan berpengaruh signifikan terhadap variabel Pembangunan Manusia, sedangkan variabel pengeluaran pemerintah sektor kesehatan tidak berpengaruh secara signifikan terhadap Pembangunan Manusia (Christina Usmaliadanti, 2011).

Analisis yang mempengaruhi timgkat kemiskinan provinsi-provinsi di Indonesia. hasil dari penelitian menyatakan bahwa Produk Domestik Regional 
Bruto Atas Dasar Harga Konstan berpengaruh negatif signifikan terhadap Tingkat Kemiskinan, Rata-Rata Lama Sekolah berpengaruh negatif signifikan terhadap Tingkat Kemiskinan, Upah Minimum Regional berpengaruh negatif signifikan terhadap Tingkat Kemiskinan, Tingkat Pengangguran berpengaruh positif signifikan terhadap Tingkat Kemiskinan, dan Tingkat Inflasi berpengaruh positif signifikan Terhadap Tingkat Kemiskinan. Berdasarkan hasil penelitian, variabel independen baik secara keseluruhan mempengaruhi secara signifikan dan sesuai dengan teori yang ada, sehingga dapat dipacu melalui program-program pemerintah guna menurunkan Tingkat Kemiskinan yang ada (Muza Al Jundi, 2014).

Penelitian yang dilakukan oleh Yani Mulyaningsih (2008) yang berjudul Pengaruh Pengeluaran Pemerintah di Sektor Publik Terhadap Peningkatan Pembangunan Manusia dan Pengurangan Kemiskinan. Penelitian ini bertujuan untuk menganalisis pengaruh pengeluaran pemerintah di sector pendidikan dan kesehatan terhadap pembangunan manusia dan pengaruhnya terhadap kemiskinan di Indonesia serta melihat hubungan pembangunan manusia terdap pengurangan kemiskinan 33 provinsi di Indonesia. Hasil dari penelitian ini menunjukan bahwa tidak ada pengaruh pengeluaran pemerintah di sektor kesehatan dan pendidikan terhadap pembangunan manusia. Hal ini disebabkan karena masih rendahnya pengeluaran pemerintah di sektor pendidikan dan kesehatan. Pengeluaran pemerintah disektor publik juga tidak terbukti mempengaruhi kemiskinan, selain itu dalam model ke tiga pembangunan manusia berpengaruh terhadap pengurangan kemiskinan. 
Peningkatan PAD akan mendorong pertumbuhan ekonomi daerah. Adanya kenaikan PAD akan memicu dan memacu pertumbuhan ekonomi daerah menjadi lebih baik daripada pertumbuhan ekonomi daerah sebelumnya. Penelitian yang dilakukan Endah Wulan (2012), Budi Santoso dan Retno Puji Rahayu (2003) menemukan hubungan yang negatif antara pendapatan asli daerah dan tingkat kemiskinan, apabila pendapatan asli daerah yang tinggi maka tingkat kemiskinan akan rendah.

Salah satu persoalan pembangunan dasawarsa ini adalah usaha untuk mengurangi jumlah penduduk miskin. Untuk mengoptimalkan dan mengelola PAD yang berdampak pada pertumbuhan ekonomi dan selanjutnya berimbas pada penekanan tingkat pengangguran dan mengurangi kemiskinan, maka diperlukan pengelolaan alokasi anggaran sebagai salah satu strategi pengelolaan pendapatan. Strategi alokasi anggaran ini bisa mendorong dan mempercepat pertumbuhan ekonomi sekaligus menjadi alat mengurangi kesenjangan / ketimpangan regional (Kuncoro, 2003).

Tujuan dari penelitian ini adalah untuk menganalisis hubungan beberapa variabel. Adapun tujuan penelitian ini adalah 1). Untuk menganalisis pengaruh pertumbuhan ekonomi dan pendapatan asli daerah terhadap kualitas pembangunan sumber daya manusia di kabupaten / kota Provinsi Bali. 2). Untuk menganalisis pengaruh pertumbuhan ekonomi, pendapatan asli daerah dan kualitas pembangunan sumber daya manusia terhadap tingkat kemiskinan di kabupaten / kota Provinsi Bali. 3). Untuk menganalisis pengaruh tidak langsung pertumbuhan ekonomi dan 
pendapatan asli daerah terhadap tingkat kemiskinan melalui kualitas pembangunan sumber daya manusia di kabupaten / kota Provinsi Bali.

Obyek dari penelitian ini berfokus pada pengaruh masing-masing variabel pertumbuhan ekonomi dan pendapatan asli daerah terhadap kualitas pembangunan manusia dan tingkat kemiskinan kabupaten/kota Provinsi Bali. Obyek penelitian dengan kurun waktu dari 2009-2016 dikarenakan pada tahun-tahun tersebut terjadinya penigkatan ataupun penurunan yang signifikan pada masing-masing variabel.

\section{METODE PENELITIAN}

Pada penelitian ini termasuk dalam jenis penelitian dengan menggunakan analisis jalur. Penelitian ini didasarkan pada pendekatan kuantitatif yang berbentuk asosiatif. Berdasarkan permasalahan yang diteliti, penelitian ini digolongkan pada penelitian asosiatif (hubungan), yaitu penelitian yang bertujuan untuk mengetahui hubungan dari dua variabel atau lebih (Sugiyono, 2013:5).. Penelitian dilakukan pada pemerintah daerah kabupaten/kota di Bali. Sasaran penelitian ini bertujuan untuk mengetahui pertumbuhan ekonomi, pendapatan asli daerah, kualitas pembangunan masnusia dan tingkat kemiskinan. Data-data yang diperoleh langsung dari pustaka tercetak yang ada pada Badan Pusat Statistik Provinsi Bali.

Variabel terikat dalam penelitian ini adalah tingkat kemiskinan. Tingkat kemiskinan merupakan persentase penduduk yang berada di bawah garis kemiskinan yang telah ditetapkan oleh Badan Pusat Statistika dibandingkan dengan 
jumlah penduduk secara keseluruhan masing-masing Provinsi di Indonesia. Dihitung dalam satuan persen.

Variabel bebas dalam penelitian adalah pertumbuhan ekonomi dan pendapatan asli daerah di Provinsi Bali. Pertumbuhan ekonomi merupakan proses kenaikan output per kapita yang di proyeksikan dengan pertumbuhan PDRB perkapita. Dalam penelitian ini PDRB diproyeksikan dengan menggunakan pertumbuhan PDRB kabupaten/kota di Provinsi Bali atas dasar harga konstan 2010 menurut lapangan usaha periode 2010-2016. Satuan dari pertumbuhan ekonomi adalah persen. Pendapatan asli daerah merupakan pendapatan yang diperoleh daerah pada Provinsi Bali yang dipungut pemerintah daerah berdasarkan peraturan perundang-undangan yang berlaku. Sektor pendapatan daerah diambil dari pajak daerah, retribusi daerah, dan lain-lain pendapatan daerah yang sah, melalui sektor ini dapat dilihat sejauh mana suatu daerah dapat membiayai kegiatan pemerintah dan pembangunan yang dihitung dalam ribuan rupiah.

Variabel interevening dalanm penelitian ini adalah indeks pembangunan manusia. Indeks Pembangunan Manusia (IPM) yaitu suatu pengukuran perbandingan dari harapan hidup, melek huruf, pendidikan, daya beli masyarakat dan standar hidup untuk semua negara seluruh dunia. IPM digunakan untuk mengklarifikasi apakah sebuah negara adalah negara maju, negara berkembang atau negara terbelakang dan juga untuk mengukur pengaruh dari kebijaksanaan ekonomi terhadap kualitas hidup pada Provinsi Bali dalam nilai absolut. Data kuantitatif dalam penelitian ini adalah pertumbuhan ekonomi, pendapatan asli daerah, kemiskinan dan indeks pembangunan manusia. Data kualitatif dalam penelitian ini 
berupa penjelasan, keterangan-keterangan yang berbentuk kata, kaliamat, sekema dan gambar mengenai variabel yang diteliti.

Data sekunder dalam penelitian ini diperoleh melalui publikasi laporan Badan Pusat Statistik. Data sekunder adalah data yang tidak langsung diperoleh dari perusahaan, melainkan diperoleh dari sumber-sumber lain baik melalui individu maupun dokumen. Data sekunder dalam laporan ini pertumbuhan ekonomi, pendapatan asli daerah, indeks pembangunan manusia, dan tingkat kemiskinan.

Teknik analisis yang digunakan dalam penelitian ini adalah analisis jalur (path analysis). Pada tahap analisis, data diolah dan diproses menjadi kelompokkelompok, diklasifikasikan, dikategorikan dan dimanfaatkan untuk memperoleh kebenaran sebagai jawaban dari masalah dalam hipotesis yang diajukan dalam penelitian. Penelitian yang dilakukan ini bermaksud untuk mengungkapkan adanya hubungan atau pengaruh antara variabel bebas atau independent variable dengan variabel terikat atau dependent variable. Dalam statistika, metode analisis yang sesuai dengan permasalahan tersebut adalah analisis jalur (path analysis) dan pengolahan data menggunakan program SPSS. Variabel terikat dipengaruhi oleh beberapa variabel bebasnya, dan antara variabel bebas terdapat hubungan. Koefisien jalur merupakan besarnya pengaruh dari suatu variabel penyebab ke variabel akibat dan diberi simbol $\mathrm{p}_{\mathrm{XY}}$. Besarnya pengaruh dari $\mathrm{X}$ terhadap $\mathrm{Y}$ dinyatakan oleh besarnya nilai numerik koefisien jalur yaitu $\rho_{Y x}$. Koefisien jalur dilihat dengan membuat persamaan $\mathrm{Y}_{1}$ dan $\mathrm{Y}_{2}$

$$
\begin{aligned}
& Y_{1}=b_{1} X_{1}+b_{2} X_{2}+e_{1} \ldots \ldots \ldots \\
& Y_{2}=b_{3} X_{1}+b_{4} X_{2}+b_{5} Y_{1}+e_{2}
\end{aligned}
$$




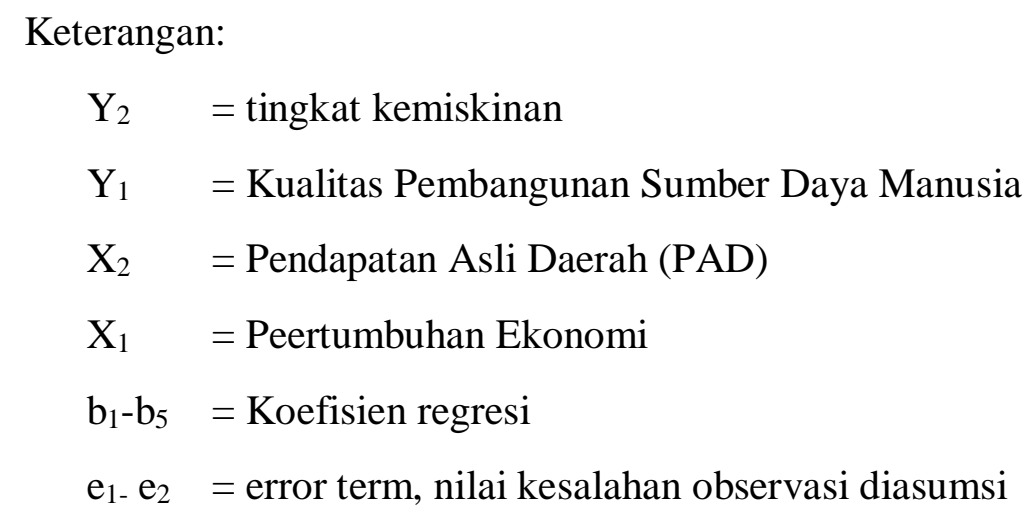

\section{HASIL DAN PEMBAHASAN}

Tabel 4.

\section{Hasil Statistik Deskriptif}

\begin{tabular}{lcccccc}
\hline & & $\mathrm{N}$ & Minimum & Maximum & Mean & Std. Deviation \\
\hline PDRB & $\left(\mathrm{X}_{1}\right)$ & 54 & 4,93 & 9,63 & 6,3247 & 0,70665 \\
PAD & $\left(\mathrm{X}_{2}\right)$ & 54 & 22961,00 & 3001464 & 460223,4 & 657560,1 \\
$\mathrm{IPM}$ & $\left(\mathrm{Y}_{1}\right)$ & 54 & 64,68 & 82,58 & 73,3305 & 3,75669 \\
Kemiskinan $\left(\mathrm{Y}_{2}\right)$ & 54 & 2,06 & 7,44 & 4,9577 & 1,39069 \\
Valid N & 54 & & & & \\
\multicolumn{2}{l}{$\begin{array}{l}\text { llistwise) } \\
\text { Sumber: } \text { Data diolah, } 2019\end{array}$}
\end{tabular}

Berdasarkan tabel 4 dapat dilihat, maka dapat dijelaskan bahwa Pertumbuhan Ekonomi $\left(\mathrm{X}_{1}\right)$ menunjukkan nilai minimum adalah 4,93 (dalam persen) dan nilai maksimumnya adalah 9,63 (dalam persen). Mean untuk pertumbuhan ekonomi adalah 6,3247 (dalam persen), hal ini berarti rata-rata pertumbuhan ekonomi sebesar 6,3247. Standar deviasinya 0,70665.

Pendapatan asli daerah $\left(\mathrm{X}_{2}\right)$ menunjukkan nilai minimum adalah $\mathrm{Rp}$ 22.961,00 (dalam ribu rupiah) dan nilai maksimumnya adalah Rp 3001464 (dalam ribu rupiah). Mean untuk pendapatan asli daerah adalah $\mathrm{Rp} 460.223,4$ (dalam ribu rupiah), hal ini berarti rata-rata pendapatan asli daerah sebesar Rp 460.223,4. Standar deviasinya 657.560,1. 
Indeks pembangunan manusia $\left(\mathrm{Y}_{1}\right)$ menunjukkan nilai minimum adalah 64,68 (dalam persen) dan nilai maksimumnya adalah 82,58 (dalam persen). Mean untuk indeks pembangunan manusia adalah 73,3305 (dalam persen), hal ini berarti rata-rata indeks pembangunan manusia sebesar 73,3305 (dalam persen) . Standar deviasinya 3,75669. kemiskinan $\left(\mathrm{Y}_{2}\right)$ menunjukkan nilai minimum adalah 2,06 dan nilai maksimumnya adalah 7,44. Mean untuk kemiskinan adalah 4,9577, hal ini berarti rata-rata kemiskinan sebesar 4,9577 Standar deviasinya 1,39069.

Pengujian data pada penelitian ini menggunakan analisis jalur (path analysis) guna menguji pola hubungan yang mengungkapkan pengaruh variabel atau seperangkat variabel terhadap variabel lainnya, baik pengaruh langsung maupun pengaruh tidak langsung. Analisis ini dilakukan dengan tahapan sebagai berikut.

Secara teoritis, hubungan antar variabel dapat dibuat model dalam bentuk diagram path,

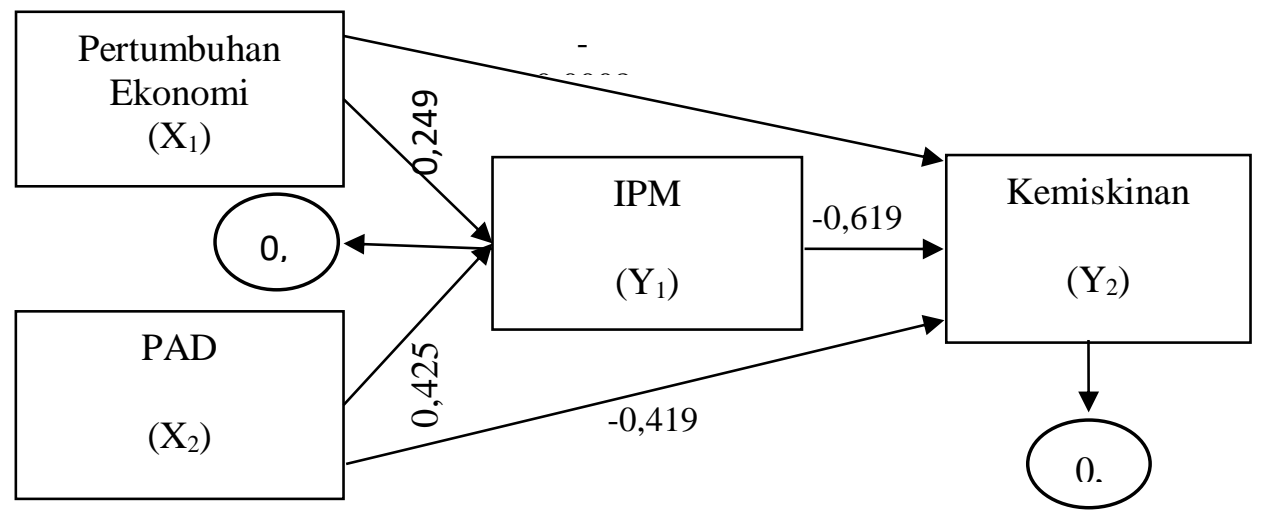

Gambar 1.

Model Jalur Hubungan Variabel Pertumbuhan Ekonomi, Pendapatam Asli Daerah dan Kualitas Pembangunan Sumber Daya Manusia terhadap

Sumber: Data diolah, 2017

\section{Kemiskinan.}


Model tersebut juga dapat dinyatakan dalam bentuk persamaan, sehingga membentuk sistem persamaan berikut.

$$
\begin{aligned}
& \hat{Y}_{1}=0,249 X_{1}+0,425 X_{2} \ldots \ldots \ldots \ldots \ldots \\
& \hat{Y}_{2}=-0,0008 X_{1}-0,410 X_{2}-0,619 Y_{1}
\end{aligned}
$$

Untuk pemeriksaan terhadap asumsi ini, dapat dilakukan dengan melihat susunan model teoritis yang telah dibangun dengan memperlihatkan bentuk hubungan antar variabel adalah linier, yaitu sistem aliran ke satu arah, dimana hubungan antara ei saling bebas demikian juga hubungan antara ei dengan variabel x saling bebas, dan tidak ada variabel endogen yang mempunyai pengaruh bolak balik.

Analisis jalur menyatakan bahwa, pengaruh langsung dinyatakan dengan koefisien $\rho_{\mathrm{i}}$, sedangkan pengaruh tidak langsung dan pengaruh total dapat dihitung dengan membuat perhitungan tersendiri. Untuk pendugaan parameter dilakukan dengan analisis regresi melalui software SPSS 24.0 for Windows diperoleh hasil sebagai berikut;

Substruktur 1:

$$
\hat{Y}_{1}=0,249 X_{1}+0,425 X_{2}+0,688
$$

Dari hasil perhitungan pada pengujian data diperoleh hasil pada tabel 5

\begin{tabular}{|c|c|c|c|c|c|c|}
\hline & \multirow{2}{*}{ Model } & \multicolumn{2}{|c|}{$\begin{array}{l}\text { Unstandardize } \\
\text { Coefficients }\end{array}$} & \multirow{2}{*}{$\begin{array}{c}\text { Standardize } \\
\text { Coefficients } \\
\text { Beta }\end{array}$} & \multirow[t]{2}{*}{$\mathbf{T}$} & \multirow{2}{*}{ Sig } \\
\hline & & B & Std. Error & & & \\
\hline \multirow[t]{3}{*}{1} & (Constant) & 63,826977 & 4,054873 & & 15,740809 & ,000000 \\
\hline & $\mathrm{X}_{1}$ & 1,325544 & ,651956 & ,249342 & 2,033179 & ,047255 \\
\hline & $\mathrm{X}_{2}$ & ,000002 & ,000001 & ,425944 & 3,473222 & ,001057 \\
\hline
\end{tabular}

Tabel 5.

\section{Coefficients Substruktur 1}


Substruktur 2:

$\hat{Y}_{2}=-0,0008 X_{1}-0,410 X_{2}-0,619 Y_{1}+0,19$

Dari hasil perhitungan pada pengujian data diperoleh hasil pada tabel 6

Tabel 6.

\section{Coefficients Substruktur 2}

\begin{tabular}{|c|c|c|c|c|c|}
\hline \multirow[t]{2}{*}{ Model } & \multicolumn{2}{|c|}{$\begin{array}{l}\text { Unstandardize } \\
\text { Coefficients }\end{array}$} & \multirow{2}{*}{$\begin{array}{c}\text { Standardize } \\
\text { coefficients } \\
\text { Beta }\end{array}$} & \multirow[t]{2}{*}{$\mathbf{T}$} & \multirow[t]{2}{*}{ Sig } \\
\hline & B & Std. Error & & & \\
\hline $\begin{array}{l}1 \\
\text { (Constant) }\end{array}$ & 22,178 & 1,929 & & 11,495 & ,000 \\
\hline $\mathrm{X}_{1}$ &,- 0016207 & ,1332565 &,- 0008235 &,- 0121622 & 9903446, \\
\hline $\mathrm{X}_{2}$ &,- 0000009 & ,0000002 &,- 4104512 & $-5,66786$ & ,0000007 \\
\hline $\mathrm{Y}_{1}$ &,- 2292463 & ,02775271 &,- 6192641 & $-8,32801$ &, 0000000 \\
\hline
\end{tabular}

Sumber: Data diolah, 2017

Berdasarkan perhitungan terhadap substruktur 1, dan 2, maka dapat diketahui besarnya pengaruh langsung, pengaruh tidak langsung dan pengaruh total antar variabel. Perhitungan pengaruh antar variabel adalah sebagai berikut.

Berdasarkan Gambar 1 dapat dihitung pengeruh langsung, pengaruh tidak langsung dan pengaruh total antar variabel

Tabel 7.

Hasil Pengaruh Langsung, Pengaruh Tidak Langsung dan Pengaruh Total Antar Variabel

\begin{tabular}{lcccc}
\hline $\begin{array}{c}\text { Hubungan } \\
\text { Variabel }\end{array}$ & PL & Pengaruh & PTL & Total \\
\hline $\mathrm{X} 1 \rightarrow$ Y1 & 0,249 & & & 0,249 \\
$\mathrm{X} 2 \rightarrow$ Y1 & 0,425 & & $-0,154131$ & 0,425 \\
$\mathrm{X} 1 \rightarrow$ Y2 & $-0,0008$ & $-0,263075$ & $-0,154931$ \\
$\mathrm{X} 2 \rightarrow$ Y2 & $-0,410$ & & $-0,673075$ \\
Y1 $\rightarrow$ Y2 & $-0,619$ & & $-0,619$ \\
\hline
\end{tabular}

Sumber: Data diolah, 2017

Keterangan :

PL : Pengaruh Langasung

PTL : Pengaruh Tidak Langsung

TP : Total Pengaruh 


\section{$\mathrm{X}_{1} \quad$ : Pertumbuhan Ekonomi (PDRB) \\ $\mathrm{X}_{2} \quad$ : Pendapatan Asli Daerah \\ $\mathrm{Y}_{1} \quad$ : Kualitas pembangunan manusia (IPM) \\ $\mathrm{Y}_{2} \quad$ : Tingkat Kemiskinan}

Berdasarkan Tabel 7 pengaruh langsung variabel $\mathrm{X}_{1}$ terhadap variabel $\mathrm{Y}_{1}$ adalah 0,249 . Tidak terdapat pengaruh tidak langsung sehingga pengaruh totalnya adalah 0,249. Pengaruh langsung variabel $\mathrm{X}_{1}$ terhadap variabel $\mathrm{Y}_{2}$ adalah $-0,0008$. Pengaruh tidak langsung variabel $\mathrm{X}_{1}$ terhaddap $\mathrm{Y}_{2}$ melalui $\mathrm{Y}_{1}$ diperoleh dari 0,249 $\mathrm{x}-0,619=-0,154131$. Oleh karena itu, pengaruh total variabel $\mathrm{X}_{1}$ terhadap variabel $\mathrm{Y}_{2}$ melalui $\mathrm{Y}_{1}$ adalah sebesar $-0,0008+-0,154131=-0,154931$

Pengaruh langsung variabel X2 terhadap Y1 adalah 0,425. Tidak terdapat pengaruh tidak langsung sehingga pengaruh totalnya adalah 0,425 . Pengaruh langsung variabel X2 terhadap variabel Y2 adalah -0,410. Pengaruh tidak langsung variabel X2 terhadap variabel Y2 melalui Y1 adalah $0,425 \times-0,619=0,263075$. Oleh karena itu, pengaruh total X2 terhadap Y2 melalui Y1 adalah sebesar -0,410 $+-0,263075=0,673075$

Persamaan struktur untuk model penelitian ini adalah :

Substruktur 1:

$Y=0,249 X_{1}+0,425 X_{2}+0,688$

$\mathrm{e}_{1}=\sqrt{1-R^{2}}$

$\mathrm{e}_{1}==\sqrt{1-0,312}=0,688$

Substruktur 2:

$Y_{2}=-0,0008 X_{1}-0,410 X_{2}-0,619 Y_{1}+0,19$

$\mathrm{e}_{2}=\sqrt{1-R^{2}}$ 
$\mathrm{e}_{2}=\sqrt{1-0,810}=0,19$

Ada dua indikator untuk melakukan pemeriksaan validitas model, yaitu koefisien determinasi total dan theory triming dimana hasilnya dapat disajikan sebagai berikut:

$\mathrm{R}_{\mathrm{m}}^{2}=1-(0,688)^{2}(0,19)^{2}$

$\mathrm{R}_{\mathrm{m}}^{2}=0,983$

Artinya, keragaman data yang dapat dijelaskan oleh model adalah sebesar 98,3 persen atau dengan kata lain informasi yang terkandung dalam data sebesar 98,3 persen dapat dijelaskan oleh model, sedangkan sisanya yaitu 1,7 persen dijelaskan oleh variabel lain (tidak terdapat dalam model) dan error.

\section{SIMPULAN DAN SARAN}

Simpulan dari penelitian ini adalah 1). Pertumbuhan ekonomi berpengaruh positif dan signifikan terhadap kualitas pembangunan sumber daya manusia di Provinsi Bali. Pendapatan asli daerah berpengaruh positif dan signifikan terhadap kualitas pembangunan sumber daya manusia di Provinsi Bali. 2). Pertumbuhan ekonomi berpengaruh tidak signifikan terhadap tingkat kemiskinan di Provinsi Bali. Pendapatan asli daerah berpengaruh tidak signifikan terhadap tingkat kemiskinan di Provinsi Bali. 3). Pertumbuhan ekonomi berpengaruh signifikan terhadap tingkat kemiskinan melalui kualitas pembangunan sumber daya manusia di Provinsi Bali. Pendapatan asli daerah berpengaruh signifikan terhadap tingkat kemiskinan melalui kualitas pembangunan sumber daya manusia di Provinsi Bali, jadi kualitas pembangunan sumber daya manusia memang benar memediasi secara penuh 
pertumbuhan ekonomi terhadap tingkat kemiskinan dan memediasi secara parsial pendapatan asli daerah terhadap tingkat kemiskinan di Provinsi Bali.

Pemerintah daerah perlu meningkatkan kualitas sumber daya manusia melalui penigkatan derajat kesehatan masyarakat dan penigkatan akses pendidikan sampai ke plosok daerah. Pemerintah daerah diharapkan lebih mampu menggali sumbersumber pendapatan asli daerah dan memperhatikan investasi dalam negeri dan anggaran yang dikeluarkan baik disektor pendidikan maupun di sektor kesehatan agar anggaran yang dikeluarkan dapat terdistribusi dengan baik. Pemerintah harus memperhatikan tingkat pendidikan yang merupakan faktor penting dalam menunjang pembangunan nasional serta peningkatan dalam pertumbuhan ekonomi.

\section{REFERENSI}

Adipuryanti, Ni Luh Putu Yuni; Sudibia, I Ketut. Analisis Pengaruh Jumlah Penduduk Yang Bekerja Dan Investasi Terhadap Ketimpangan Distribusi Pendapatan Melalui Pertumbuhan Ekonomi Kabupaten/Kota Di Provinsi Bali. Piramida, [S.L.], V. 11, N. 1, July 2015. Issn 1907-3275. Available At: <Https://Ojs.Unud.Ac.Id/Index.Php/Piramida/Article/View/18710>. Date Accessed: 22 Mar. 2019.

Anom Iswara, I Made dan I Gusti Bagus Indrajaya. 2014. Pengaruh Pendapatan Asli Daerah, Pendapatan Perkapita, Dan Tingkat Pendidikan Terhadap Tingkat Kemiskinan Di Provinsi Bali Tahun 2006 - 2011. E-Jurnal EP Unud 3(11) : 492-501.

Artana Yasa, I Komang Oka; Arka, Sudarsana. Pengaruh Pertumbuhan Ekonomi dan Disparitas Pendapatan Antardaerah Terhadap Kesejahteraan Masyarakat Provinsi Bali. Jurnal Ekonomi Kuantitatif Terapan, [S.1.], nov. 2015. ISSN 2303-0186. Available at: <https://ojs.unud.ac.id/index.php/jekt/article/view/16494>. Date accessed: 11 sep. 2017. Vol. 8, No. 1, pp: 1-112

Barimbing, Yesika Resianna dan Luh Karmini. 2015. Pengaruh PAD, Tenaga Kerja, dan Investasi Terhadap Pertumbuhan Ekonomi Di Provinsi Bali. E-Jurnal Ekonomi Pembangunan Universitas Udayana . 4(5): 434-450. 
Cahyani, Ratih dan Darsana. 2016. Analisis Pertumbuhan Ekonomi Bali Tahun 1996-2013. E-Jurnal Ekonomi Pembangunan Unud. 5(5) : 557-577

Christina, Usmaliadanti. 2011. Analisis Pengaruh Tingkat Kemiskinan, Pengeluaran Pemerintah Sektor Pendidikan, Dan Kesehatan Terhadap Indek Pembangunan Manusia Di Provinsi Jawa Tengah Tahun 20072009. Skripsi. Universitas Diponegoro.

Fajri, Muhammad; Delis, Arman; Amzar, Yohanes Vyn. Dampak Otonomi Fiskal, Pertumbuhan Ekonomi, dan Keterbukaan Daerah Terhadap Ketimpangan Wilayah di Sumatera. Jurnal Ekonomi Kuantitatif Terapan, [S.1.], jan. 2017. ISSN 2303-0186. Available at: <https://ojs.unud.ac.id/index.php/jekt/article/view/27422>. Date accessed: $04 \quad$ oct. 2018. doi: https://doi.org/10.24843/JEKT.2017.v09.i02.p02.

Hariwan, Peggy; Swaningrum, Ayu. Analisis Indeks Pembangunan Manusia Pada 5 Wilayah Hasil Pemekaran Di Jawa Barat. Jurnal Ekonomi Kuantitatif Terapan, [S.1.], nov. 2015. ISSN 2303-0186. Available at: <https://ojs.unud.ac.id/index.php/jekt/article/view/16496>. Date accessed: $04 \quad$ oct. 2018. doi: https://doi.org/10.24843/JEKT.2015.v08.i01.p08.

Mahesha, Dr.D., Shivalingappa, Dr. B.N. 2011. Regional Disparities of Human Resource Development in South India. E-International Scientific Research Journal. 3(4): 216-415

Muza, AL. Jundi. 2014. Analisis Faktor Yang Mempengaruhi Tingkat Kemiskinan Provinsi-Provinsi Di Indonesia. Skripsi. Universitas Dipoenogoro Semarang. Dipublikasikan

Natasha Hamilton-Hart \& Günther G. Schulze (2016) Taxing Times in Indonesia: The Challenge of Restoring Competitiveness and the Search for Fiscal Space. Bulletin of Indonesian Economic Studies. 52 (3): 265-295

Pauzi, Ahmad, dan Budiana. 2016. Faktor-Faktor Yang Mempengaruhi Secara Langsung Maupun Tidak Langsung Ketimpangan Distribusi Pendapatan Provinsi Bali. E-Jurnal EP Unud. 5(6): 668-691

Rustariyuni, Surya Dewi. Pengaruh Gini Ratio, Pengeluaran Non Makanan Per Kapita, Belanja Daerah Dan Laju Pertumbuhan Ekonomi Pada Indeks Pembangunan Manusia Kabupaten/Kota Di Provinsi Bali Periode 20042012. Piramida, [S.L.], V. 10, N. 1, July 2014. Issn 1907-3275. Available At: <Https://Ojs.Unud.Ac.Id/Index.Php/Piramida/Article/View/15954>. Date Accessed: 22 Mar. 2019.

Seran, Sirilius. Hubungan antara Pendidikan, Pengangguran, dan Pertumbuhan Ekonomi dengan Kemiskinan. Jurnal Ekonomi Kuantitatif Terapan, [S.1.], may 2017. ISSN 2303-0186. Available at: <https://ojs.unud.ac.id/index.php/jekt/article/view/23023>. Date 
accessed:

04

oct.

2018.

doi: https://doi.org/10.24843/JEKT.2017.v10.i01.p07.

Sri Budhi, Made Kembar. Analisis Faktor-faktor Yang Berpengaruh Terhadap Pengentasan Kemiskinan Di Bali: Analisis FEM Data Panel. Jurnal Ekonomi Kuantitatif Terapan, [S.1.], feb. 2013. ISSN 2303-0186. Available at: <https://ojs.unud.ac.id/index.php/jekt/article/view/4506>. Date accessed: 04 oct. 2018.

Sugiyono. 2013. Metode Penelitian Bisnis (Pendekatan Kuantitatif, Kualitatif, dan $R \& D)$. Bandung: Alfabeta.

Suryahadi, Asep, Gracia Hadiwijaya, dan Sudarno Sumarto. 2012. Economic Growth and Poverty Reduction in Indonesia Before and After the Asian Financial Crisis. Bulletin of Indonesian Economic Studies, 48(2): 209227.

Suwandika, Putu Eka dan I Nyoman Mahaendra Yasa.2015. Pengaruh Pendapatan Asli Daerah dan Investasi Terhadap Pertumbuhan Ekonomi dan Tingkat Pengangguran di Provinsi Bali. E-Jurnal Ekonomi Pembangunan Univesitas Udayana. 4(7): 794-810.

Vincent, Brian.2009.The Concept'Provety' towards Understanding in The Context of Development. E-International Scientific Research Journal. 2(2): 22934

Yogi Swara, Wayan; Jember, I Made. Kemiskinan Di Bali. Piramida, [S.L.], Nov. 2012. Issn 1907-3275. Available At: < Https://Ojs.Unud.Ac.Id/Index.Php/Piramida/Article/View/3017>. Date Accessed: 27 June 2019. 